\title{
Factors associated with seropositivity for anti-Toxoplasma gondii antibodies in pregnant women of Londrina, Paraná, Brazil
}

\author{
FMR Lopes', R Mitsuka-Breganó1, DD Gonçalves', RL Freire', CJT Karigyo², GF Wedy², T Matsuo ${ }^{3}$, \\ EMV Reiche ${ }^{4}$, HK Morimoto ${ }^{4}$, JD Capobiango ${ }^{5}$, IT Inoue ${ }^{6}$, JL Garcia', IT Navarro'+ \\ ${ }^{2}$ Graduação em Medicina ${ }^{3}$ Departamento de Estatística e Matemática Aplicada ${ }^{4}$ Departamento de Patologia, Analises Clínicas e \\ Toxicologia ${ }^{5}$ Departamento de Clínica Médica ${ }^{6}$ Departamento de Ginecologia e Obstetrícia ${ }^{1}$ Departamento de Medicina Veterinária \\ Preventiva, Universidade Estadual de Londrina, Paraná, Brasil
}

The aim of this study was to evaluate associations between seropositivity for IgG and IgM anti-Toxoplasma gondii antibodies and socio-economic and environmental variables in pregnant women of Londrina, state of Paraná, Brazil. We interviewed 492 pregnant women, each of whom answered an epidemiological questionnaire, and collected blood samples for measurement of IgG and IgM anti-T. gondii antibodies by chemiluminescence. A confirmatory diagnosis of acute infection was made by an IgG avidity test. Titres of specific IgG anti-T. gondii were obtained by IFAT. Seropositivity for IgG anti-T. gondii antibodies was observed in 242 women (49.2\%) and, of these, six pregnant women (1.2\%) showed seropositivity for IgM. Age group, level of education, per capita income, presence of a cat in the house and a habit of eating green vegetables were all factors associated with a greater chance of infection with $\mathrm{T}$. gondii. This study showed that 250 (50.8\%) pregnant women were susceptible to $\mathrm{T}$. gondii and considered to be at high risk for toxoplasmosis during pregnancy. Based on the results obtained, is critical to establish a program of health surveillance for toxoplasmosis, in order to contribute to diagnosis and early treatment during the prenatal period. It is also necessary to introduce measures to prevent the Toxoplasma infection in seronegative pregnant women.

Key words: Toxoplasma gondii - congenital toxoplasmosis - pregnant women - epidemiology

Congenital toxoplasmosis occurs when Toxoplasma gondii, an obligatory intracellular protozoan, reaches the foetus transplacentally. More than $90 \%$ of pregnant women who acquire a primary infection during gestation are asymptomatic (Montoya \& Rosso 2005). T. gondii infection can be acquired by ingesting sporulated oocysts found in dirt, sand and food, or ingesting tissue cysts found in raw or rare pork, lamb or sheep (Frenkel 2002).

In general, among all pregnant women who acquire an infection for the first time, $61 \%$ will not transmit it to the foetus: $26 \%$ of cases will present foetus with subclinical infection and $13 \%$ will present clinical infection ( $7 \%$ severe infection and 6\% mild infection) (Dunn et al. 1999). Identifying the gestational age at primary infection is crucial for the clinical management of pregnant women, since the severity of toxoplasmosis for the foetus decreases and the transmission rate increases with increasing gestational age (Beguetto et al. 2003). In the United State, rates of congenital toxoplasmosis have been estimated between one per 10,000 and 10 per 10,000 live births each year (Lopez et al. 2000).

Toxoplasmosis is usually diagnosed based on the detection of specific IgG and IgM antibodies; however, the inclusion of other parameters such as IgG avidity, IgA,

Financial support: SETI-PR, SESA-PR, UEL, CNPq

+ Corresponding author: italmar@uel.br

Received 10 October 2008

Accepted 23 March 2009 and IgE tests and polymerase chain reaction is fundamental for a conclusive diagnosis of toxoplasmosis during pregnancy (Jones et al. 2003). Therefore, laboratory diagnosis poses a challenge for health care professionals not only because of the complexity in the interpretation of these markers, but also because modern laboratory techniques are not always available in the national public health care system (Mozzatto \& Procianoy 2003).

The aim of this study was to evaluate associations between seropositivity for IgG and IgM anti-T. gondii antibodies and socio-economic and environmental variables in women in the first trimester of pregnancy in the Basic Health Units of Londrina, state of Paraná (PR), Brazil.

\section{SUBJECTS, MATERIALS AND METHODS}

This study was approved by the Research Ethical Committee from Londrina State University, under number 047/05. Pregnant women who had pre-natal checkups in all Basic Health Units and were in the first trimester of pregnancy were included following their free and informed consent. Samples were collected between May-December 2006 (with a gap between August-November due to a strike in the public health service of the city). A total of 492 blood samples were submitted for the measurement of anti-T. gondii IgG and IgM antibodies by the Municipal Central Laboratory.

In order to determine the size of the sample population, it was estimated that the Basic Health Units of Londrina attend 5,000 pregnant women each year. This number was obtained based on data provided by the $\mathrm{Mu}-$ nicipal Health Office of Londrina. Using an expected 
prevalence of $50 \%$, error of $5 \%$ and significance level of $5 \%$, the sample size obtained was 350 .

The city of Londrina has 497,833 inhabitants, with 6,872 live births (IPARDES 2009) and 5,000 pregnant women per year in the prenatal of the Basic Health Units. The climate is classified as subtropical humid, with an average annual temperature above $20^{\circ} \mathrm{C}$. Agriculture (e.g., coffee, corn, wheat, vegetables) and livestock (poultry and cattle) are the main economic activities. The water that supplies the city is captured in the Tibagi and Cafezal Rivers and is distributed to the public according to standards set by the World Health Organization (SANEPAR 2009).

Chemiluminescence's technology was used for the quantitative determination of specific anti-T. gondii $\operatorname{IgG}$ and IgM antibodies (LIAISON ${ }^{\circledR}$, DiaSorin S.p.A., Salluggia, Italy).

Samples were considered IgG reactive when the antibody concentration was greater than or equal to $8.8 \mathrm{UI} /$ $\mathrm{mL}$, non-reactive when the concentration was less than $7.2 \mathrm{UI} / \mathrm{mL}$, and undetermined when the concentration was between 7.2 and $8.8 \mathrm{UI} / \mathrm{mL}$. Samples were considered reactive for IgM when the antibody concentration was greater than or equal to $8.0 \mathrm{UA} / \mathrm{mL}$, non-reactive when the concentration was less than $6.0 \mathrm{UA} / \mathrm{mL}$, and undetermined when the concentration was between 6.0 and $8.0 \mathrm{UA} / \mathrm{mL}$. In order to confirm the undetermined results, new samples were collected after 15 days.

Samples that were reactive to both anti-T. gondii IgG and IgM were sent to the Clinical Immunology Laboratory of University Hospital of Londrina State University (HU-UEL) in order to confirm acute infection using an IgG avidity test. A semi-quantitative titre of anti-T. gondii $\operatorname{IgG}$ antibodies was also determined by IFAT (Camargo 1974).

In order to determine the sociodemographic characteristics that could be associated with $T$. gondii infection, each pregnant woman answered a questionnaire with information about pregnancy, eating and hygiene habits, in addition to social-economic variables. Information was stored and analyzed in the EpiInfo program (Dean et al. 1994). Chi-squared or Fisher Exact tests, when appropriate, were used to verify the statistical significance and the Odds Ratio (OR) as a measure of the association between toxoplasmosis infection and other variables studied. A significance level of 5\% was used in this study. In order to evaluate the independent association of the factors evaluated, a multivariate regression analysis of factors with $p<0.20$ in the bivariate analysis was applied.

\section{RESULTS}

The prevalence of specific anti- $T$. gondii IgG was of 49.2\% (CI 95\%: 44.7-53.6\%) (Table I). In that group, six women $(1.2 \%)$ were found to be IgM reactive. The average age of all pregnant women was $25.7 \pm 6.7$ years.

Data from the evaluated sociodemographic characteristics that could be associated with the serological results for anti-T. gondii antibodies are presented in Table II. Variables such as age group $(\mathrm{p}=0.033)$, education level $(\mathrm{p}<0.001)$, per capita income $(\mathrm{p}<0.001)$, presence
TABLE I

Prevalence of anti-Toxoplasma gondii $\operatorname{IgG}$ and IgM antibodies obtained in pregnant women from the Basic Health Units in Londrina, Paraná, 2006

\begin{tabular}{lcc}
\hline $\begin{array}{l}\text { Antibodies } \\
\text { anti-T. } \text { gondii }^{a}\end{array}$ & $\begin{array}{c}\text { Prevalence } \\
\mathrm{n}(\%)\end{array}$ & CI 95\% \\
\hline $\mathrm{IgG}(+) \operatorname{IgM}(-)$ & $236(48.0)$ & \\
$\operatorname{IgG}(+) \operatorname{IgM}(+)$ & $6(1.2)$ & $44.7-53.6$ \\
Total IgG(+) & $242(49.2)$ & \\
$\operatorname{IgG}(-) \operatorname{IgM}(+)$ & $4(0.8)$ & \\
$\operatorname{IgG}(-) \operatorname{IgM}(-)$ & $246(50.0)$ & $46.3-55.2$ \\
\hline Total $\operatorname{IgG}(-)$ & $250(50.8)$ & \\
\hline
\end{tabular}

$a$ : IgG and IgM antibodies against $T$. gondii were evaluated by chemioluminescence reaction LIAISON ${ }^{\circledR}$, DiaSorin). Semiquantitative titer of IgG anti-T. gondii was also evaluated by immunofluorescent assay test.; CI: confidence interval; +: reactive; -: non-reactive.

of cats $(\mathrm{p}=0.004)$ and habit of eating vegetables $(\mathrm{p}=$ 0.003 ) that showed significant association with the presence of $\operatorname{IgG}$ antibodies were analyzed in the multivariate logistic regression model (Table III).

\section{DISCUSSION}

The prevalence of anti- $T$. gondii IgG antibodies observed in this study (49.2\%) is in agreement with previous seropositivity data reported in Brazil, which has varied from $31 \%$ in pregnant women from Caxias do Sul, state of Rio Grande do Sul (RS), Southern Brazil, up to $91.6 \%$ in pregnant women from Mato Grosso do Sul, Central Western region of Brazil (Detanico \& Basso 2006, Figueiró-Filho et al. 2007). According to Buffolano (2008), climate plays an indirect role in allowing more (in the case of a moist and hot climate) or less (in the case of a dry and cold climate) survival of oocysts in the environment.

The number of cases of IgM reactivity, observed in 10 women $(2.0 \%)$, was greater than that $(0.4 \%)$ found by Figueiró-Filho et al. (2007) in pregnant women from the Central Western region of Brazil, using an enzymelinked immunosorbent assay (ELISA). On the other hand, our results were similar to those found by Reiche et al. (2000), who observed $1.8 \%$ IgM seropositivity using an ELISA method in women at the University Hospital in the city of Londrina, PR, during the period from 1996-1998. However, these results are lower than those found by Detanico and Basso (2006) (5.5\%) in pregnant women from Caxias do Sul, RS, Southern region of the country, by using enzyme linked fluorescent assay.

Currently, IgM serological tests show high sensitivity and are able to detect very low concentrations of this immunoglobulin. Seropositivity for IgM antibodies can persist for several months or even years after seroconversion; therefore, the IgM titre cannot be used by itself as a reliable marker of acute infection (Liesenfeld et al. 2001). Further testing for an elevated or rising IgG level, low IgG avidity, positive IgA antibodies, or a combination of these is suggested in women showing $\operatorname{IgG}$ and 


\section{TABLE II}

Analysis of sociodemographic characteristics of pregnant women attended at Basic Health Units in Londrina, Paraná, 2006, according to the seropositivity for anti-Toxoplasma gondii $\mathrm{IgG}$ antibodies

\begin{tabular}{|c|c|c|c|}
\hline $\begin{array}{l}\text { Sociodemographic characteristics } \\
\text { IgG antibodies/total (\%) }\end{array}$ & Reactive anti- $T$. gondii & Odds ratio (CI 95\%) & $\mathrm{p}$ \\
\hline \multicolumn{4}{|l|}{ Residence } \\
\hline Urban zone & $228 / 468(48.7)$ & $0.68(0.30-1.56)$ & $0.358^{b}$ \\
\hline Rural zone & $14 / 24(58.3)$ & & \\
\hline \multicolumn{4}{|l|}{ Age group (years) } \\
\hline $13-20$ & $53 / 131(40.5)$ & 1.0 (reference) & $0.024^{b}$ \\
\hline $21-30$ & $131 / 255(51.4)$ & $1.55(1.01-2.38)$ & \\
\hline $31-48$ & $58 / 106(54.7)$ & $1.78(1.06-2.98)$ & \\
\hline \multicolumn{4}{|l|}{ Education level } \\
\hline complete or incomplete 1st grade & $123 / 205(60.0)$ & 1.0 (reference) & $<0.001^{b}$ \\
\hline complete or incomplete 2 nd grade & $109 / 255(42.7)$ & $0.50(0.34-0.72)$ & \\
\hline complete or incomplete 3 rd grade & $10 / 32(31.3)$ & $0.30(0.14-0.67)$ & \\
\hline \multicolumn{4}{|l|}{ Per capita income ${ }^{a}$} \\
\hline$<\mathrm{R} \$ 150.00$ & $95 / 154(61.7)$ & 1.0 (reference) & $<0.001^{b}$ \\
\hline $\mathrm{R} \$ 151.00-\mathrm{R} \$ 350.00$ & $94 / 198(47.5)$ & $0.56(0.37-0.86)$ & \\
\hline$>\mathrm{R} \$ 351.00$ & $53 / 137(38.7)$ & $0.39(0.24-0.63)$ & \\
\hline \multicolumn{4}{|l|}{ Water consumption from the public system } \\
\hline Yes & $234 / 478(49.0)$ & $0.72(0.25-2.10)$ & $0.546^{c}$ \\
\hline No & $8 / 14(57.1)$ & 1.0 (reference) & \\
\hline \multicolumn{4}{|l|}{ Presence of vegetable garden at home } \\
\hline Yes & $29 / 65(44.6)$ & $0.81(0.48-1.37)$ & $0.429^{c}$ \\
\hline No & 213/427 (49.9) & 1.0 (reference) & \\
\hline \multicolumn{4}{|l|}{ Presence of cats in home } \\
\hline Yes & $37 / 55(67.34)$ & $2.33(1.28-4.21)$ & $0.004^{c}$ \\
\hline No & 205/437(46.9) & 1.0 (reference) & \\
\hline \multicolumn{4}{|l|}{ Presence of dogs in home } \\
\hline Yes & $144 / 299(48.2)$ & $0.90(0.63-1.29)$ & $0.571^{c}$ \\
\hline No & 98/193 (50.8) & 1.0 (reference) & \\
\hline \multicolumn{4}{|l|}{ Consumption of raw or rare meat } \\
\hline Yes & $92 / 181(50.8)$ & $1.11(0.77-1.60)$ & $0.578^{c}$ \\
\hline No & $150 / 311(48.2)$ & 1.0 (reference) & \\
\hline \multicolumn{4}{|l|}{ Habit of manipulating dirt or sand } \\
\hline Yes & $33 / 62(53.2)$ & $1.20(0.71-2.05)$ & $0.496^{c}$ \\
\hline No & $209 / 430(48.6)$ & 1.0 (reference) & \\
\hline \multicolumn{4}{|l|}{ Habit of eating raw vegetables } \\
\hline Yes & $235 / 463(50.8)$ & $3.24(1.36-7.73)$ & $0.005^{c}$ \\
\hline No & $7 / 29(24.1)$ & 1.0 (reference) & \\
\hline
\end{tabular}

$a$ : R B Brazilian currency (R\$ $1.00=\mathrm{U} \$ 1.70$, approximately) (three pregnant women did not report data on income); $b$ : Chisquare test for trend; $c$ : Chi-square test of Pearson; CI: confidence interval.

IgM seropositivity in their first prenatal test. None of these tests reliably determines the timing of parasitaemia, and furthermore, sequential use of highly sensitive IgM assays and methods for examining IgG avidity or stage specificity in the first 12 weeks gestational age could reasonably exclude post-conceptional infection in an expectant mother (Buffolano 2008).

Six $(1.2 \%)$ reactive $\operatorname{IgG}$ and IgM samples showed strong avidity, indicating infection in the past four months. Since all pregnant women taking part in this study were in their first trimester of pregnancy when routine serology for toxoplasmosis was performed, this result suggests infection prior to conception and, there- fore, minimal risk of congenital infection. In one of these patients, though, the IgG titre was $1: 16.000$ by IFAT, indicating a possible recent infection. This was the only pregnant woman directed to specific treatment for toxoplasmosis in the reference hospital in the region. This result shows the importance of quantifying antibody levels, mainly IgG, for the definition of acute cases.

Four other samples $(0.8 \%)$ were reactive for $\operatorname{IgM}$ and non-reactive for IgG. These pregnant women underwent a new serologic evaluation after 15 days, with the same diagnostic tests, and presented the same results, suggesting false positive or non-specific IgM antibodies. This demonstrates the importance of confirming previous se- 


\section{TABLE III}

Multi-varied logistic regression for IgG anti-Toxoplasma gondii positive samples obtained from pregnant women attended at the Basic Health Units in Londrina, Paraná, 2006, according to the sociodemographic characteristics evaluated

\begin{tabular}{|c|c|c|c|c|}
\hline \multirow{2}{*}{$\begin{array}{l}\text { Sociodemographic characteristics } \\
\text { Age group (years) }\end{array}$} & \multirow[t]{2}{*}{ Odds ratio } & \multicolumn{2}{|c|}{ OR (CI 95\%) } & \multirow[t]{2}{*}{$\mathrm{p}$} \\
\hline & & & & \\
\hline $21-30 / 13-20$ & 1.90 & 1.20 & 3.00 & 0.006 \\
\hline $31-48 / 13-20$ & 1.93 & 1.00 & 3.36 & 0.021 \\
\hline \multicolumn{5}{|l|}{ Education level } \\
\hline $\begin{array}{l}\text { complete or incomplete 2nd grade/ } \\
\text { complete or incomplete 1st grade } \\
\text { complete or incomplete 3rd grade/ }\end{array}$ & 0.54 & 0.36 & 0.81 & 0.003 \\
\hline complete or incomplete 1st grade & 0.31 & 0.13 & 0.71 & 0.006 \\
\hline \multicolumn{5}{|l|}{ Per capita income $e^{a}$} \\
\hline $\mathrm{R} \$ 151.00-\mathrm{R} \$ 350.00 /<\mathrm{R} \$ 150.00$ & 0.62 & 0.39 & 0.97 & 0.038 \\
\hline$>\mathrm{R} \$ 351.00 /<\mathrm{R} \$ 150.00$ & 0.45 & 0.27 & 0.75 & 0.003 \\
\hline \multicolumn{5}{|l|}{ Presence of cats in home } \\
\hline yes/no & 2.19 & 1.17 & 4.11 & 0.015 \\
\hline \multicolumn{5}{|l|}{ Habit of eating raw vegetables } \\
\hline yes/no & 3.91 & 1.56 & 9.80 & 0.004 \\
\hline
\end{tabular}

$a$ : R\$ Brazilian currency (R\$1.00 = U\$ 1.70, approximately); CI: confidence interval; OR: odds ratio.

ropositivity results. A thorough analysis of $\mathrm{IgM}$ results is very important to avoid exposing both the mother and the foetus to unnecessary procedures such as treatment and amniocentesis, which can be harmful for both.

When considering age group, the prevalence of IgG antibodies in our study population increased with age (from 31-48 years old). Despite regional differences - whether due to environment, cultural and/or eating habits - similar results were found by Spalding et al. (2005) in pregnant women in RS. This can be explained by the increase of exposure to infection sources throughout life.

Pregnant women with a low per capita income $(<\mathrm{R} \$ 150.00)$ and a low education level (complete or incomplete 1st grade corresponding to a basic education) had greater risk of infection with $T$. gondii. Similar findings were reported by Avelino et al. (2004), where pregnant women from Goiannia, state of Goiás (GO), in the Central Western region of Brazil, with a lower education level and low income (less than two minimum wages) showed a greater chance of acquiring toxoplasmosis. Varella et al. (2003) reported that, among all variables studied, the one carrying the greatest risk for toxoplasmosis was an education level less than nine years $(\mathrm{OR}=2.2)$. Liu et al. (2009) studied 235 pregnant women in Changchun, China, and found that a low education level was a risk factor for toxoplasmosis. These results underscore the importance of investing in education as a means of promoting health among the population.

The presence of cats in the homes of the pregnant women was also associated with a greater chance of infection by $T$. gondii. Avelino et al. (2004) analyzed groups of pregnant and non-pregnant women in Goiânia, $\mathrm{GO}$, and verified that the presence of a cat was a risk factor only for pregnant women. The authors declared that having a cat at home, by itself, was not enough to increase the risk of acquiring a $T$. gondii infection. According to Dubey (2000), direct contact with cats is ir- relevant for $T$. gondii transmission; therefore, that study only evaluated the presence of cats in the environment, which could lead to soil contamination.

A habit of eating raw vegetables was also considered to be a factor associated with a greater chance of $T$. gondii infection. Our findings are in agreement with those reported by Avelino et al. (2004) in pregnant women from Goiânia, GO.

Despite Cook et al. (2000) having reported that the consumption of raw or rare meat was an important risk factor for toxoplasmosis in pregnant women, this variable was not significant in the present study. It was also not significant in the study carried out by Avelino et al. (2004). These contradictory results could be explained by the drastic reduction of the prevalence of toxoplasmosis in the swine population in the Northern region of PR, one of the most important species in the transmission of toxoplasmosis to the human population in Brazil (Vidotto et al. 1990, Tsutsui et al. 2003, Olbrich-Neto \& Meira 2004, Carletti et al. 2005, Dias et al. 2005). This reduction likely occurred as a result of increased technology and sanitary improvements adopted on swine farms over the last 15 years.

There was no significant association of $T$. gondii infection with either the habit of manipulating dirt and sand by pregnant women or the presence of a vegetable garden at home. These data differed from the results of Spalding et al. (2005) in pregnant women in RS, where contact with soil was the greatest risk factor associated with $T$. gondii infection.

These differences in factors associated with infection underscore the need for regional studies in order to determine epidemiologic and sociodemographic characteristics specific for each population, allowing the development of targeted methods for control and prophylaxis for toxoplasmosis. 
This study revealed high seropositivity for IgG antibodies for toxoplasmosis in pregnant women $(49.2 \%)$; however, $50.8 \%$ of women studied were susceptible during pregnancy. Age, low per capita income, low education level, the presence of cats in the home and ingestion of raw vegetables were all factors associated with a greater risk of $T$. gondii infection.

\section{ACKNOWLEDGEMENTS}

To the Municipal Health Office of Londrina (Basic Health Units and CENTROLAB) and to the University Hospital from Londrina State University.

\section{REFERENCES}

Avelino MM, Campos-Júnior D, Parada JB, Castro AM 2004. Risk factors for Toxoplasma gondii infection in women of childbearing age. Braz J Infect Dis 8: 164-174.

Beguetto E, Buffolano W, Spadoni A, Del Pezzo M, Di Cristina M, Minenkova O, Petersen E, Felici F, Gargano N 2003. Use of an Immunoglobulin G Avidity Assay based on recombinant antigens for diagnosis of primary Toxoplasma gondii infection during pregnancy. J Clin Microbiol 41: 5414-5418.

Buffolano W 2008. Congenital toxoplasmosis: The state of the art. Parassitologia 50: 37-43.

Camargo ME 1974. Introdução às técnicas de imunofluorescência. Rev Bras Patol Clín 10: 87-107.

Carletti RT, Freire RL, Shimada MT, Ruffolo BB, Begale LP, Lopes FMR, Navarro IT 2005. Prevalência da infecção por Toxoplasma gondii em suínos abatidos no Estado do Paraná, Brasil. Semina, Ciências Agrárias 26: 563-568.

Cook AJC, Gilbert RE, Buffolano W, Zufferey J, Petersen E, Jenum PA, Foulon W, Semprini AE, Dunn DT, Holliman R 2000. Sources of Toxoplasma infection in pregnant women: European multicentre case-control study. Br Med J 321: 142-147.

Dean AG, Dean JA, Coulomerier D, Brendel KA, Smith DC, Burton AH, Dicker RC, Sulivan KM, Fagan RF, Arner TG 1994. Epi Info, version 6: a word processing, data bases, and statistic program for epidemiology on microcomputers. Center for Diseases Control and Prevention, Atlanta, Georgia, USA.

Detanico L, Basso RMC 2006. Toxoplasmose: perfil sorológico de mulheres em idade fértil e gestantes. Rev Bras An Clín 38: 15-18.

Dias RAF, Navarro IT, Ruffolo BB, Bugni FM, Castro MV, Freire RL 2005. Toxoplasma gondii em lingüiça de carne suína tipo frescal, com investigação soroepidemiológica em trabalhadores de estabelecimentos produtores. Rev Inst Med Trop Sao Paulo 47: 185-189.

Dubey JP 2000. Sources of Toxoplasma gondii infection in pregnancy. Br Med J 32: 127-128.

Dunn D, Wallon M, Peyron F, Petersen E, Peckhan C, Gilbert R 1999. Mother-to-child transmission of toxoplasmosis: risk estimates for clinical counseling. Lancet 353: 1829-1833.

Figueiró-Filho EA, Senefonte FRA, Lopes AHA, Morais OO, Souza Júnior VG, Maia TL, Duarte G 2007. Freqüência das infecções pelo HIV-1, rubéola, sífilis, toxoplasmose, citomegalovírus, herpes simples, hepatite B, hepatite C, doença de Chagas e HTLV I/
II em gestantes do Estado de Mato Grosso do Sul. Rev Soc Bras Med Trop 40: 181-187.

Frenkel JK 2002. Toxoplasmose. In R Veronesi, Tratado de Infectologia, 2nd ed., Atheneu, São Paulo, p. 1310-1325.

IPARDES - Instituto Paranaense de Desenvolvimento Econômico e Social [homepage on the Internet]. [cited $2009 \mathrm{Feb}$ 05]. Available from: http://www.ipardes.gov.br/perfil_municipal/MontaPerfil. php?Municipio $=86000 \&$ btOk $=$ ok .

Jones JL, Lopez A, Wilson M, Schulkin J, Gibbs R 2003. Congenital toxoplasmosis: a Review. Obstet Gynecol Surv 56: 296-305.

Liesenfeld O, Montoya JG, Kinney S, Press C, Remington JS 2001. Effect of testing for IgG Avidity in the diagnosis of Toxoplasma gondii infection in pregnant women: experience in a referencel. $J$ Infect Dis 183: 1248-1253.

Liu Q, Wei F, Gao S, Jiang L, Lian H, Yuan B, Yuan Z, Xia Z, Liu B, $\mathrm{Xu} X$, Zhu XQ 2009. Toxoplasma gondii infection in pregnant women in China. Trans R Soc Trop Med Hyg 103: 162-166.

Lopez A, Dietz VJ, Wilson M, Navin TR, Jones JL 2000. Preventing congenital toxoplasmosis. MMWR Recomm Rep 49: 59-68.

Montoya JG, Rosso F 2005. Diagnosis and management of Toxoplasmosis. Clin Perinatol 32: 705-726.

Mozzatto L, Procianoy RS 2003. Incidence of congenital toxoplasmosis in Southern Brazil: a prospective study. Rev Inst Med Trop Sao Paulo 45: 147-151.

Olbrich-Neto J, Meira DA 2004. Soroprevalência de vírus linfotrópico de células T humanas, vírus da imunodeficiência humana, sífilis e toxoplasmose em gestantes de Botucatu - São Paulo - Brasil. Fatores de risco para vírus linfotrópico de células T humana. Rev Soc Bras Med Trop 37: 28-32.

Sanepar - Companhia de Saneamento do Paraná - Paraná 2009. [cited 2009Feb 05]. Available from:http://www.sanepar.com.br/sanepar/ calandrakbx/calandra.nsf/0/1335E061E927FB3B8325703300496 D80?OpenDocument\&pub=T\&proj=InternetSanepar.

Reiche EMV, Morimoto HK, Farias GN, Hisatsugu KR, Geller L, Gomes ACLF, Inoue HY, Rodrigues G, Matsuo T 2000. Prevalência de tripanossomíase americana, sífilis, toxoplasmose, rubéola, hepatite $\mathrm{B}$, hepatite $\mathrm{C}$ e da infecção pelo vírus da imunodeficiência humana, avaliada por intermédio de testes sorológicos, em gestantes atendidas no período de 1996 a 1998 no Hospital Universitário Regional Norte do Paraná (Universidade Estadual de Londrina, Paraná, Brasil). Rev Soc Bras Med Trop 33: 519-527.

Spalding SM, Amendoeira MRR, Klein CH, Ribeiro LC 2005. Serological screening and toxoplasmosis exposure factors among pregnant women in South of Brazil. Rev Soc Bras Med Trop 38: 173-177.

Tsutsui VS, Navarro IT, Freire RL, Freitas JC, Prudêncio LB, Delbem ACB, Marana ERM 2003. Soroepidemiologia e fatores associados à transmissão do Toxoplasma gondii em suínos do norte do Paraná. Arch Vet Sci 8: 27-34.

Varella IS, Wagner MB, Darela AC, Nunes LM, Muller RW 2003. Prevalência de soropositividade para a toxoplasmose em gestantes. J Pediatr 79: 69-74.

Vidotto O, Navarro IT, Giraldi N, Mitsuka R, Freire RL 1990. Estudos epidemiológicos da toxoplasmose em suínos da região de Londrina - PR. Semina, Ciências Agrárias 11: 53-59. 